\title{
Histopathological and Biochemical Toxic Effect of Amiodarone on Thyroid Gland in Albino Rat
}

\author{
Ola A. El Sayed*, Safaa E. Gawish**, \\ Gihan. H. Aweida*** and Enas A. Auda**** \\ Anatomy*, Forensic medicine \& toxicology**, biochemistry*** \\ $\&$ pharmacology department $* * * *$ \\ Al-Azhar University, Faculty of medicine for girls
}

\begin{abstract}
Backgrounds: Amiodarone AMD (Cordarone) was a benzofuran derivative, used in management of angina and refractory ventricular arrhythmia. Its effect on the thyroid gland structure and function was investigated in this study.

Material and Methods: Fifty adult male albino rats were used and divided into three groups. The first group was consisted of 10 rats which served as control, received distilled water orally $(1 \mathrm{ml})$. The second group was consisted of 20 rats used as therapeutic dose treated group, received $40 \mathrm{mg} / \mathrm{Kg} \mathrm{b}$. w. of amiodarone while the third group was consisted of 20 rats used as a toxic dose treated group which received $60 \mathrm{mg} / \mathrm{Kg} \mathrm{b}$. w. of amiodarone orally daily for three months. Body weight of animals was determined. Serum concentration of tri-iodothyonine (T3), thyroxine (T4), thyrotrophin (TSH), interleukin 6 (IL6), tumour marker P53 and tissue residue for amiodarone in plasma, fat, liver, lung, thyroid gland and heart was determined.

Results: Specimens from thyroid gland were taken and prepared for light and electron microscope examination. Highly significant decrease in body weight $(\mathrm{P}<0.001)$ were observed in both therapeutic and toxic doses treated groups in comparison to the control one. A very highly significant increase $(\mathrm{P}<0.001)$ of serum $(\mathrm{T} 4 \& \mathrm{~T} 3)$ with Concomitant suppression of (TSH) $(\mathrm{P}<0.001)$. Serum levels of IL6 and P53 showed also a very highly significant increase $(\mathrm{P}<0.001)$. Amiodarone concentration in plasma, fat, liver, lung, thyroid gland and heart showed significant increase in therapeutic dose treated group and highly significant increase in toxic dose treated group.

Histopathological examination of thyroid gland of therapeutic dose treated group by light microscope showed marked evidence of thyotoxicosis in the form of microcystic follicular changes and peripheral scalloping, cellular degeneration with scanty cytoplasm and vesicular nuclei appeared. These changes became more severe in toxic dose treated group in the form of epithelial hyperplasia with atypical nuclear features. Thyroid tissue damage with haemorrhage and necrosis. Electron microscopic examination showed a remarkable cellular changes in the form of dilated rouph endoplasmic reticulum, inclusion lysosomes, dilated Golgi bodies, mitochondrial distension and nuclear degeneration. In both treated groups these changes were dose related.
\end{abstract}

Key Words: Amiodarone - Thyroid - Gland - Rat

\section{Introduction}

Amiodarone was a potent anti arrhythmic agent, it was widely used in tachyarrhythmias and to a lesser extent, ischaemic heart disease. Amiodarone was a benzofuraric derivative whose structural formula closely resembled that of T4. It was associated with variations in thyroid gland structure and function.

However amiodarone, treated patient developed either hypothyroidism or thyroto-xicosis. (Martino, et al., 2001).
Cappiello, et al. (1995) \& Anu Bhalla (2007) reported that amiodarone induced thyrotoxicosis. It occurred with chronic treatment. Its pathogenesis was related to iodine overload or direct toxic effect of amiodarone with consequent release of iodothyronine into the circulation.

Chiovate, et al. (1994) said that (Desethyl amiodarone) DEA the main amiodarone metabolite was even more cytotoxic for thyroid cells than amiodarone 
and its intrathyroidal concentration was higher than that of the parentral drug.

Many goitrogenic xenobiotics (amiodarone) that increased the incidence of thyroid tumour in rodents exerted a direct effects on the thyroid gland to disrupt one of several steps in the biosynthesis and secretion of thyroid hormones. These inhibited the 5'monodeiodinase which converted T4 in peripheral sites (e.g Liver and Kidney) to biologically active T3. Inhibition of this enzyme lowered circulating T3 levels, which resulted in a compensatory increased secretion of thyroid stimulating hormone (TSH).

Amiodarone also induced follicular cell hypertrophy and hyperplasia and increased incidence of follicular cell tumours in rats (Capen, 1994).

Thyroid histopathology in case of amiodarone treated rats models demonstrated degenerative and destructive follicular lesions with multinuclear cell and macrophage infiltrate and focal fibrosis. Amiodarone had also showed apoptosis inducing activity. Ultrastrucural changes of thyroid cytotoxicity included marked distortion of thyroid architecture, evidence of necrosis and apoptosis inclusion bodies, lipofuscinogenesis and markedly dilated endoplasmic reticulum. AMD was directly cytotoxic to the thyroid gland by disruption of subcellular organelle function (Pitsiavas et al., 1997).

During chronic therapy of amiodarone, the drug altered thyroid hormone metabolism with a low incidence of altered thyroid state. It appeared to act by inhibiting the outer ring mono-diodination of thyroxine, thereby blocking conversion of $\mathrm{T} 4$ to tri-iodo-thyro-nine (T3), resulting in significant increase in serum $\mathrm{T} 4$ and reverse (rT3) but only a slight decrease in serum T3 (Reader et al., 1985).

Increased serum interleukin 6 (IL6) concentration had recently been reported in patients with subacute thyroiditis and in some patients with amiodarone induced thyroto-xicosis, possibly because of cytokine release from damaged thyroid cellds. Serum thyro-globulin also increased after radioactive iodine. The increase in IL6 was correlated with the size of nodule or goiter serum, thyrog-lobulin also increased (Bartalena et al., 1994).
Amiodarone and its iodide content induced apoptosis through a P53 independent mechanism involving oxidative stress and associated with production of reactive oxygen species and a marked increase in lipid peroxide levels. These mechanisms contribu-ted to amiodarone associated thyroid histopat-hological abnormalities (Holt et al., 1983).

Amiodarone was concentrated in plasma, fat, liver, lung, heart and thyroid gland in cases of acute and chronic toxicity of amiodarone when administrated to male, Wistar and albino rats. (Naggar, 2001).

The primary manifestations of amiodarone induced thyrotoxicosis (AIT) were ventricular tachycardia, exacerbation of chronic pulmonary disease and occult hyperth-yroidism, morbidity induced pneumonia and cardiac dysarrythmias. Microscopic examin-ation showed destructive follicular lesions with fibrosis in all patients, associated thyroid pathologic condition included multinodular goiter and a follicular adenoma.

Pathological examination of thyroid gland in amiodarone induced thyrotoxicosis revealed degenerative and destructive follicular changes with diffuse fibrous and lymphocytic infiltration. (Alan et al., 1991).

The purpose of this study was to determine the chronic toxic effects of therapeutic and toxic dose of amiodarone on the incidence of thyroid disorders and the changes in thyroid hormones and to determine amiodarone concentration in various tissues, plasma, fat, liver, lung, thyroid gland \& heart of experimental animals. The achievement of this aim was tried through adoption certain parameters biochemical \& histopathological examination of the thyroid gland.

\section{Material And Methods}

A) Animals: Fifty adult male albino rats weighing 200-220 gm were used. The rats were maintained under standard environmental conditions and diet. They were received the drug orally. The control animals were passed through the same sequences of handling 


\section{Ola A. EI Sayed et al}

and oral administration of the vehicle (water).

B) The drug (amiodarone hydrochloride) cordarone tablets were supplied from Global Nobi company for pharmaceuticals products under license of Sanofi Synthel abo. Each tablet contained $200 \mathrm{mg}$, which was dissolved in $5 \mathrm{ml}$ distilled water in which $2 \mathrm{ml}$ of the solvent contained $40 \mathrm{mg}$ of amiodarone hydrochloride.

C) Experimental implementation. In the following schematic representation, histopathological and biochemical will be manoeuvered for antiarrythmic drug (amiodarone). Fifty adult albino rats were used in this experiment. They were divided into three groups, the first group (group I) (10 animals) was held as control and each animal from this group was received $1 \mathrm{ml}$ of distilled water. The second group (group II) (20 animals) were used for study of adverse effect of therapeutic dose. The human therapeutic dose of amiodarone was recorded by (Hardman et al., 1996) to be $600 \mathrm{mg} /$ day. According to (Paget and Barnes, 1964). The calculated therapeutic dose for adult albino rat was found to be $(40 \mathrm{mg} / \mathrm{kg} \quad$ b.w/day) received orally for 12 weeks. The third group (group III) (20 animals) were used for study of toxic dose of amiodarone $\quad(60 \quad \mathrm{mg} / \mathrm{kg} \quad$ b.w/day $)$ received orally for 12 weeks (Kannon et al., 1991). At the end of each four weeks the animals were weighed and recorded in a comparative study.

\section{Biochemical study:}

To demonstrate the biochemical changes, blood samples were taken just prior to dissection from the venous plexus behind the orbit in a sterile centrifuge tube and allow to clot overnight $\left(4^{\circ} \mathrm{C}\right)$ and serum was separated following centrifugation (1500 per minute for $30 \mathrm{~min}$ ). Sera were stored at $-70^{\circ} \mathrm{C}$ until analysed for thyroid hormones. Thyroxine (T4), Triiodothyronine (T3) and thyroid stimulating hormone (TSH) concentration in the serum samples were determined by enzyme immunoassay (EIA) test kit according to (Kaplan, 1985). Interleukin 6 (IL6) and tumour marker (P53) were determined by enzyme linked immunosorbent assay (ELISA) (Bannes et al., 1993).

\section{Tissue residue:}

Concentration of amiodarone in plasma, heart, lung, thyroid, fat, liver and kidney was measured by high performance liquid chromatography (HPLC) (Neill, 1993 \& Naggar, 2001).

\section{Histopathological study:}

The animals were sacrified after being anaethestized with ether, then they were dissected for thyroid gland. Then, specimens were taken rapidly, fixed in $10 \%$ formalin and processed in paraffin wax, cut at 6 microns. The sections were stained by haematoxylin and eosin stain for microscopic examination (Druny and Walington, 1980). Other specim-ens were taken and cut into small pieces then fixed in gluteraldehyde and processed for electron microscopy. Ultrathin sections were contrasted with uranyl acetate and lead citrate. The specimens were dehydrated and embe-dded in Epon-Araldit resin (Hayat 1989).

\section{Statistical analysis:}

Statistical analysis was performed on IBM/PC, using SP SS/PC programme within groups difference, one-way analysis of variance (ANOVA) test was carried out. Students t-test was used between groups (Altmann, 1991).

Data for weight variations values, serum (T3), (T4), (TSH), IL6 and P53 (tumour marker), and tissue concentrations values of amiodarone in plasma, heart, lung, fat, liver and kidney were reported and presented as means \pm standard deviation $( \pm \mathrm{SD})$. For comparison of means between two treated groups, students " $\mathrm{t}$ " test was used.

\section{Results}

\section{Body weight:}

Table (1) showed very highly significant weight loss in therapeutic and toxic doses treated groups with amiodarone as compared with the control $(\mathrm{P}<0.001)$.

\section{Biochemical study:}

Table (2) showed changes in the plasma level of thyroid hormones (T3 and T4), TSH and IL6 in rats received 
therapeutic and toxic doses of amiodarone. A very highly significant increase in triiodothyronine (T3) and tetra-iodothyronine (T4) and IL6 ( $\mathrm{P}<0.001)$ and a very highly significant decrease in the level of TSH $(\mathrm{P}<0.001)$ was noticed in comparison to those of control group. Table (3) demonstrated P53 protein concentration in sera of rats received amiodarone in therapeutic and toxic dose. There were very highly significant increase in P53 in both therapeutic and toxic doses treated groups $(\mathrm{P}<0.001)$ as compared to the control group.
Table (4) showed amiodarone concentr-ation in various tissue residue. It was signifi-cantly increased $(\mathrm{P}<0.05)$ in plasma, fat, liver, lung, thyroid, and heart with highest concentration in liver and fat in therapeutic dose treated group and highly significantly increased $(\mathrm{P}<0.01)$ in toxic dose treated group compared to the control group. Morever its tissue concentration tended to be significantly higher in group III than in group II for the examined tissues indicating a dose dependent manner.

Table (1): Statistical analysis of body weight changes in treated rat groups (therapeutic and toxic doses) of aminodarone at $4,8,12$ weeks)

\begin{tabular}{|c|c|c|c|c|c|c|c|c|c|c|c|c|c|c|c|}
\hline & \multirow{2}{*}{\multicolumn{3}{|c|}{ Before treatment }} & \multicolumn{12}{|c|}{ After Treatments } \\
\hline & & & & \multicolumn{4}{|c|}{4 Weeks } & \multicolumn{4}{|c|}{8 Weeks } & \multicolumn{4}{|c|}{12 Weeks } \\
\hline $\begin{array}{c}\text { Therapeutic } \\
\text { dose treated } \\
\text { group (II) }\end{array}$ & 210 & \pm 5.58 & 0.0 & 182 & 28 & $\begin{array}{c} \pm \\
2.42\end{array}$ & $\stackrel{* * *}{64.4}$ & 154.8 & 55.2 & 2.9 & $\begin{array}{c}* * * \\
121.04\end{array}$ & 142.4 & 67.6 & 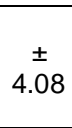 & $\begin{array}{c}* * * \\
155.84\end{array}$ \\
\hline
\end{tabular}

$\mathrm{X}=$ Mean

$\mathrm{t}=$ Unpaired "t-test".

$\mathrm{SD}=$ Standard deviation $\quad * * *$ very highly significant $=\mathrm{P}<0.001$.

Table (2) Statistical analysis of thyroid hormones and interleukin-6 in therapeutic and toxic dose treated rat groups with amiodarone.

\begin{tabular}{|c|c|c|c|c|c|c|c|c|}
\hline & \multicolumn{2}{|c|}{ T3 (ug/dL) } & \multicolumn{2}{c|}{ T4 (ug/dL) } & \multicolumn{2}{c|}{ TSH (ug/ml) } & \multicolumn{2}{|c|}{ IL-6 (pg/ml) } \\
\cline { 2 - 9 } & $\mathrm{X}$ & $\mathrm{SD}$ & $\mathrm{X}$ & $\mathrm{SD}$ & $\mathrm{X}$ & $\mathrm{SD}$ & $\mathrm{X}$ & $\mathrm{SD}$ \\
\hline Control group (I) & 5 & $\pm 0.5^{* * *}$ & 4.5 & $\pm 0.45^{* * *}$ & 2.72 & $\pm 0.27^{* * *}$ & 14.95 & $\pm 6.01^{* * *}$ \\
\hline $\begin{array}{c}\text { Therapeutic dose } \\
\text { treated group (II) }\end{array}$ & 65.6 & $\pm 6.55^{* * *}$ & 80.7 & $\pm 8.07 * * *$ & 1.5 & $\pm 0.15^{* * *}$ & 22.01 & $\pm 10.25^{* * *}$ \\
\hline $\begin{array}{c}\text { Toxic dose treated } \\
\text { group (III) }\end{array}$ & 102.3 & $\pm 10.2^{* * *}$ & 130.1 & $\pm 13.01^{* * *}$ & 0.9 & $\pm 0.09^{* * *}$ & 35.41 & $\pm 16.49^{* * * *}$ \\
\hline
\end{tabular}

$\mathrm{X}=$ Mean

$\mathrm{SD}=$ Standard deviation

$* * *=\mathrm{P}<0.001$ very highly significant

Table (3) Statistical analysis of P53 protein concentration ( $\mathrm{U} / \mathrm{ml})$ in sera of therapeutic and toxic dose treated rat groups with amiodarone.

\begin{tabular}{|l|c|l|c|}
\hline \multicolumn{1}{|c|}{ P53 protein concentration } & $\mathrm{X}$ & \multicolumn{1}{c|}{ SD } & SE \\
\hline Control group (I) & 12.65 & $\pm 0.45^{* * *}$ & 0.19 \\
\hline Therapeutic dose treated group (II) & 23.94 & $\pm 1.00^{* * *}$ & 0.34 \\
\hline Toxic dose treated group (III) & 47.88 & $\pm 2.16^{* * *}$ & 0.68 \\
\hline X= Mean & SD= Standard deviation \\
SE = Standard error & $* * *=P<0.001=$ very highly significant
\end{tabular}


Table (4) Statistical analysis of amiodarone $\mathrm{ug} / \mathrm{ml}$ concentration in various organs of rats after administration of therapeutic and toxic doses of amiodarone for 3 months in therapeutic and toxic dose.

\begin{tabular}{|c|c|r|r|r|r|r|}
\hline $\begin{array}{c}\text { Amiodarone } \\
\text { concentration }\end{array}$ & Plasma & Fat & Liver & Lung & \multicolumn{1}{c|}{ Thyroid } & Heart \\
\cline { 2 - 6 } & $\mathrm{ug} / \mathrm{ml}$ & $\mathrm{ug} / \mathrm{ml}$ & $\mathrm{ug} / \mathrm{ml}$ & $\mathrm{ug} / \mathrm{ml}$ & $\mathrm{ug} / \mathrm{ml}$ & $\mathrm{ug} / \mathrm{ml}$ \\
\hline Control group (I) & $\mathrm{ND}$ & $\mathrm{ND}$ & $\mathrm{ND}$ & $\mathrm{ND}$ & $\mathrm{ND}$ & $\mathrm{ND}$ \\
\hline $\begin{array}{c}\text { Therapeutic dose } \\
\text { treated group (II) }\end{array}$ & $\pm 0.78^{*}$ & $\pm 52.01^{*}$ & $\pm 64.43^{*}$ & $\pm 6.10^{*}$ & $\pm 1.67^{*}$ & $\pm 0.84^{*}$ \\
\hline $\begin{array}{c}\text { Toxic dose treated } \\
\text { group (III) }\end{array}$ & $\pm 1.59^{* *}$ & $\pm 105.05^{* *}$ & $\pm 129.87^{* *}$ & $\pm 14.21^{* *}$ & $\pm 3.95^{* *}$ & $\pm 1.88^{* *}$ \\
\hline
\end{tabular}

$* \mathrm{P}<0.05$ significant

$* *<0.01$ highly significant

Histopathological study:

Light microscopic examination of the control adult rats thyroid sections (group I) (HX \& E) showed that thyroid gland consisted of follicles of various sizes. Its walls were lined by cuboidal follicular epithelial cells surrounding colloid inside its lamina. Inter follicular cells were shown in between the follicles Fig. (1).

Light microscopic examination of therapeutic dose treated group with amiodarone. (Group II) showed loss of normal architecture of thyroid gland. The acini showed irregular shape and size with micro cystic follicles with peripheral scalloping and scanty amount of colloid (Fig 2). They became lined with columnar epithelium with scanty amount of cytoplasm and vesicular nuclei, The colloid showed peripheral vaculations (Fig. 3).

Light microscopic examination of toxic dose treated group with amiodarone (group III) showed marked epithelial hyperplasia of the thyroid follicles with atypical nuclear features. They were lined by stratified columnar cells. Some follicles showed obliterated lumen with absence of colloid. Fibrous tissue appeared to be increased in the stroma between the thyroid follicles (Fig. 4). The thyroid gland showed loss of its pattern with follicular damage and haemorrhage in the acini. Interstitial tissue showed areas of haemorrhage and necrosis with inflammatory cell infiltration (Fig.5).
Electron microscopic examination of the thyroid follicular cells of the control animals (group I) showed that each cell exhibited rounded nucleus, many cisternae of rough endoplasmic reticulum and scattered mitochondria (Fig. 6).

Electron microscopic examination of the thyroid follicular cells in therapeutic dose treated group with amiodarone (group II) showed dilated rouph endoplasmic reticulum and many large inclusion lysosomes in abundant amount and dilated cisternae of Golgi bodies containing secretory material (Fig. 7, 8). There was irregular nucleus with dispersed chromatin and distended mitocho-ndria with glycogen with loss of its pattern. There was also markedly dilated rouph endoplasmic reticulum (Fig.9,10).

Electron microscopic examination of the thyroid follicular cells in toxic dose treated group with amiodarone (group III) showed large irregular nucleus with irregular nucleoli and dispersed chromatin. There were secretory vesicles and granules near the lumen with distended irregular rouph endoplasmic reticulum \& lysosomal inclusion bodies (Fig. 11, 12). Some nuclei showed heterochromatin along nuclear membrane. Secretory vesicles were shown attached to cisternae of dilated endoplasmic reticulum with degenerated mitochondria and excess lysosomal element (Fig. 13). There were also markedly dilated irregular distended rouph endoplasmic reticulum, elongated mitochondria and secondary deformed lysosomes (Fig. 14). 


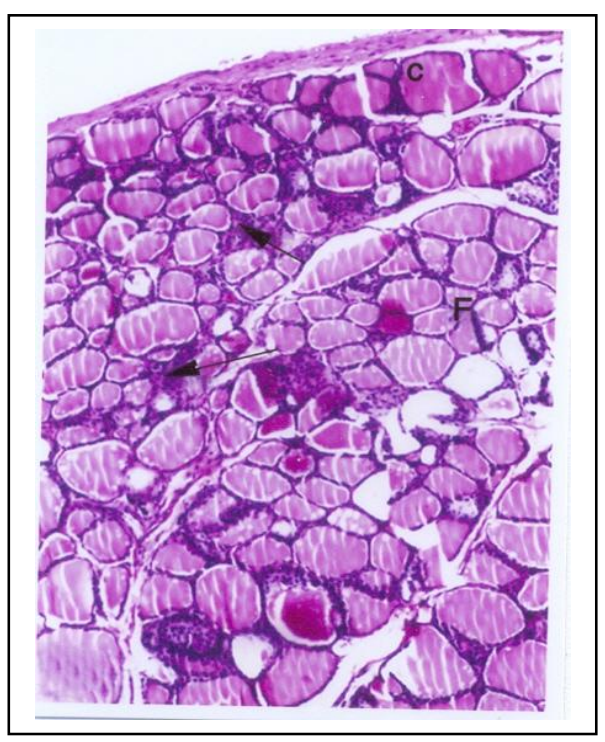

Fig. (1): A photomicrograph of thyroid gland of control rat showing follicles of various sizes $(\mathrm{F})$. Its walls are lined by cuboidal follicular cells surrounding colloid (C) inside its lumina. Interfollicular cells are shown between the follicles (arrows)

(Hx \& E X100).

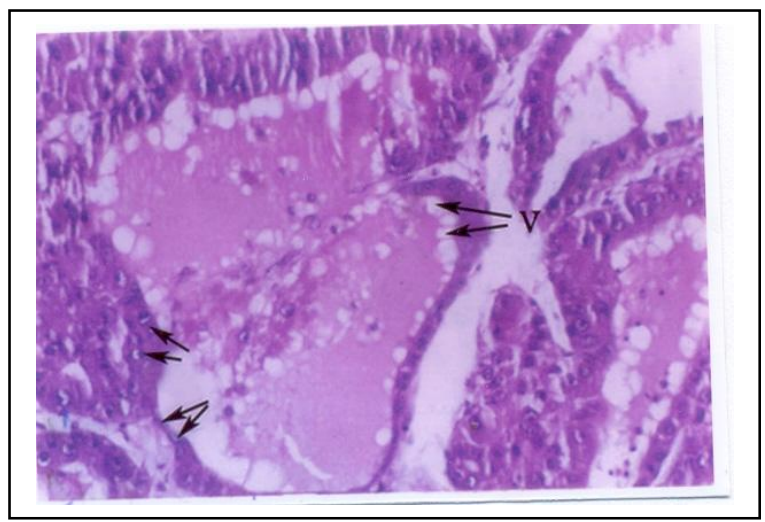

Fig (3): A photomicrograph of thyroid gland acini of therapeutic dose treated group (G II) became lined with columnar epithelium with scanty amount of cytoplasm and vesicular nuclei $\uparrow \uparrow$. The colloid showed peripheral vaculations $(\mathrm{V})$.

(Hx X 400).

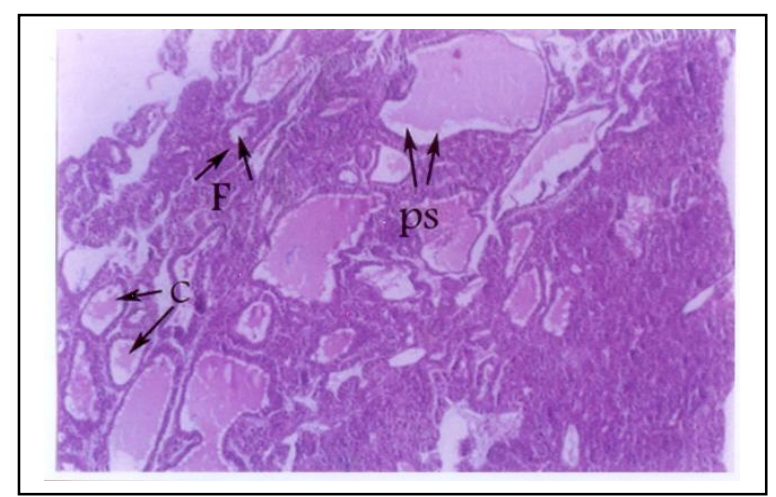

Fig. (2): A photomicrograph of thyroid gland of therapeutic dose treated group (G II) showed loss of normal architecture. The acini showed irregular shape and size with microcystic follicles (F). with peripheral scalloping (P.S.) and scanty amount of colloid (C).

(Hx \& E X 200).

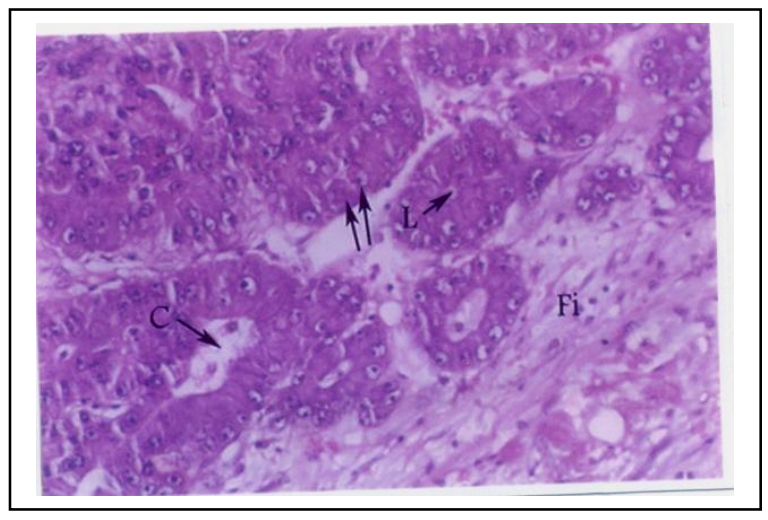

Fig. (4): A photomicrograph of thyroid follicles of toxic dose treated group (G III) showed marked epithelial hyperplasia with atypical nuclear features. They are lined by stratified columnar cells. Notice: Some follicles showed obliterated lumen (L) with absence of colloid (C). Fibrous tissue (F) appears to be increased in the stroma between thyroid follicles. (Hx \& E X 200). 


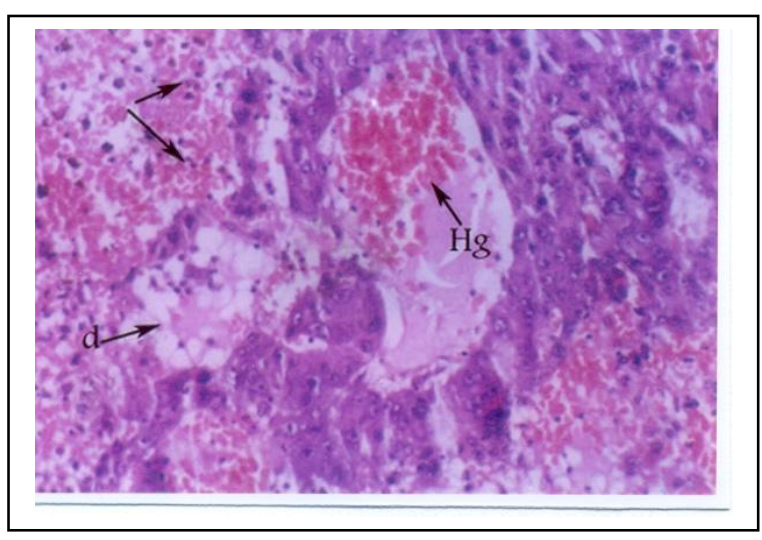

Fig. (5): A photomicrograph of the thyroid gland of toxic dose treated group (G III) shows loss of its pattern with follicular damage (d) and haemorrhage $(\mathrm{Hg})$ inside the acini. Interstitial tissues shows areas of haemorrhage and necrosis with inflammatory cell $\uparrow \uparrow$ infiltration. (Hx \& E X 400)

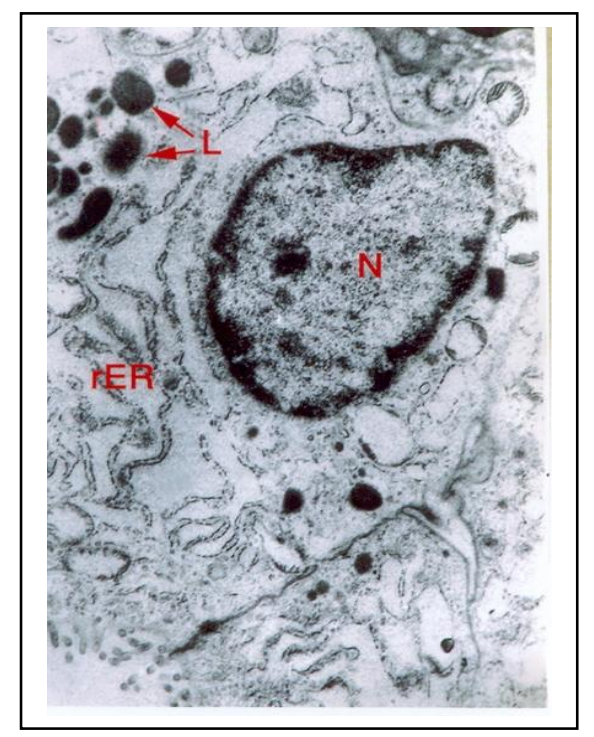

Fig. (7): An electron micrograph of thyroid follicular cells in therapeutic dose treated group showing dilated rER , many large lysosomes (L) \& irregular nucleus (N). ( X 5000)

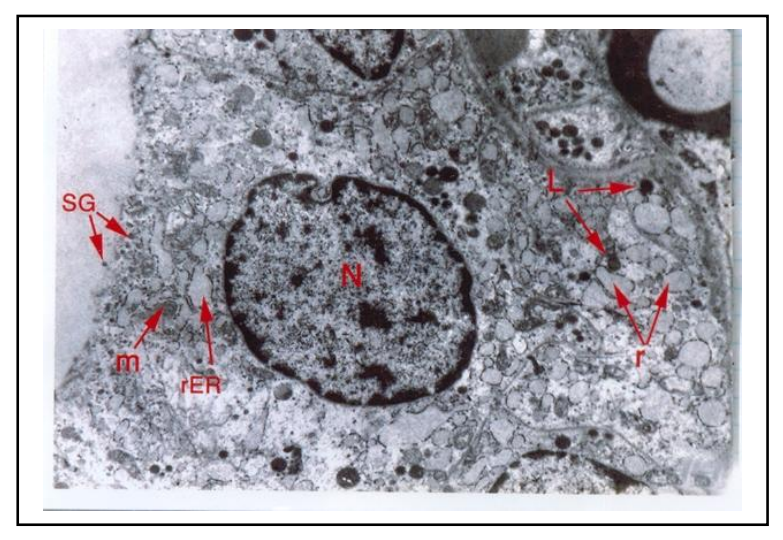

Fig. (6): An electron micrograph of thyroid follicular cells of control animals showing nucleus $(\mathrm{N})$, apical secretory granules (SG), rouph endoplasmic reticulum (rER), lysosomes (L), polyribosomes (r) \& scattered mitochondria (m)

( X 600)

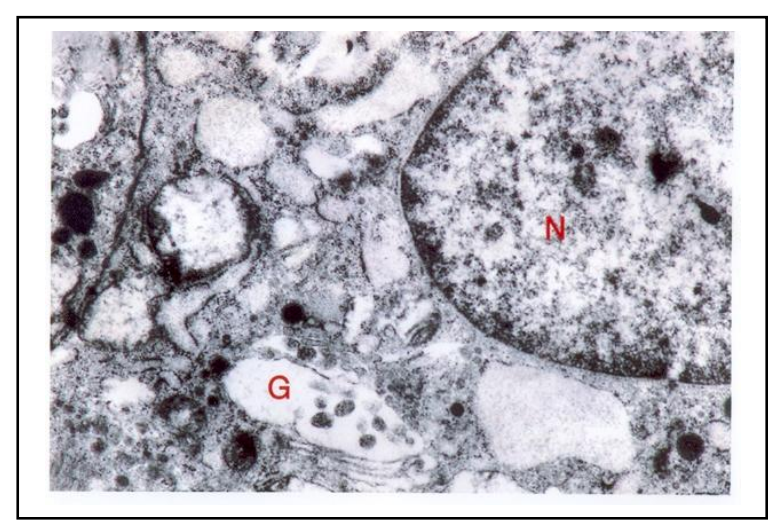

Fig (8): An electron micrograph of the basal part of thyroid follicular cells in therapeutic dose treated group showing dilated cisterna of Golgi body (G) containing secretory material.
( X 8000) 


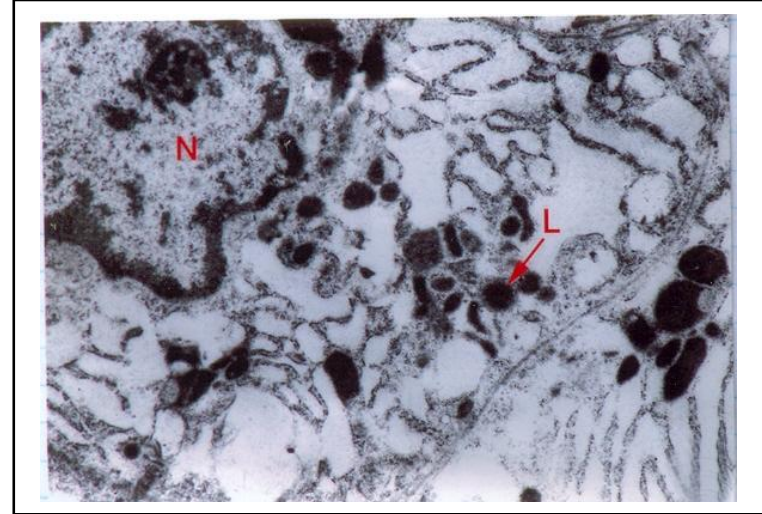

Fig. (9): An electron micrograph of the basal part of a thyroid follicular cell in therapeutic dose treated group showing abundant lysosomes (L) with irregular nucleus (N) with dispersed chromatin.

(X 10000)

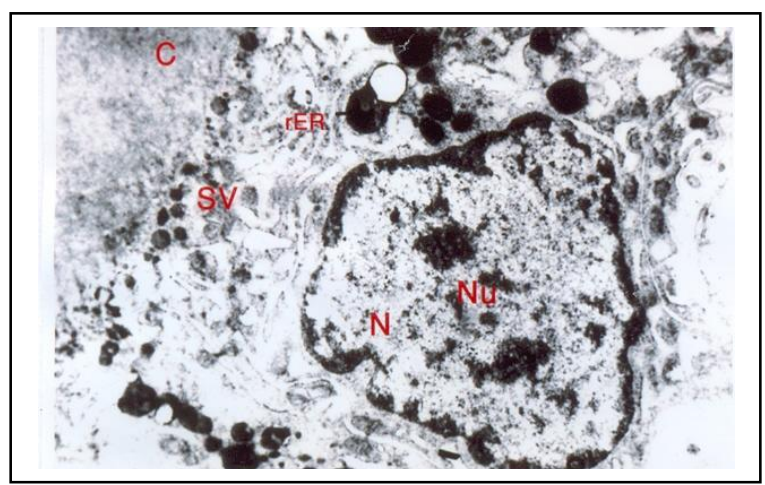

Fig. (11): Electron micrograph of follicular thyroid in toxic dose treated group showing secretory vesicles (SV), large and irregular nucleus $(\mathrm{N})$ with irregular nucleoli $(\mathrm{Nu})$ with dispersed chromatin and dilated rER. Notice the colloid $(\mathrm{C})$.

( X 5000)

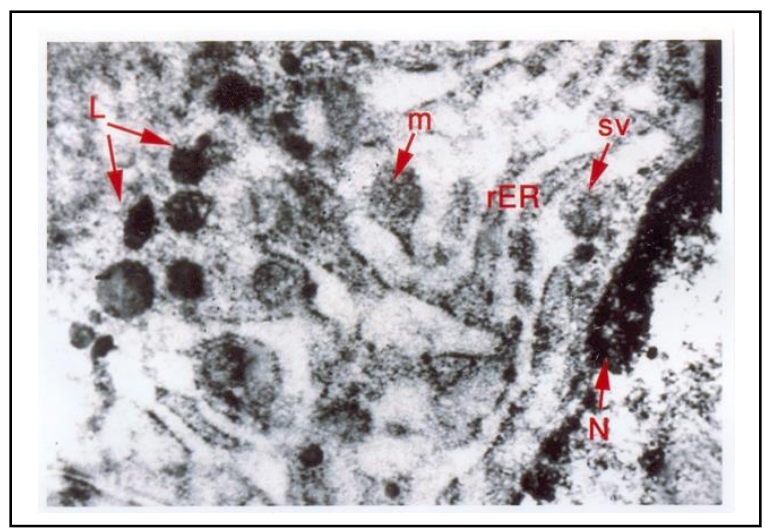

Fig. (13): Electron micrograph of follicular thyroid cell in toxic dose treated group showing secretory vesicles (SV) attached to cisternae of dilated rER and excess lysosomal element (L) with hetero chromatin along nuclear membrane $(\mathrm{N})$, degenerated mitochondria (m).

( X 10000)

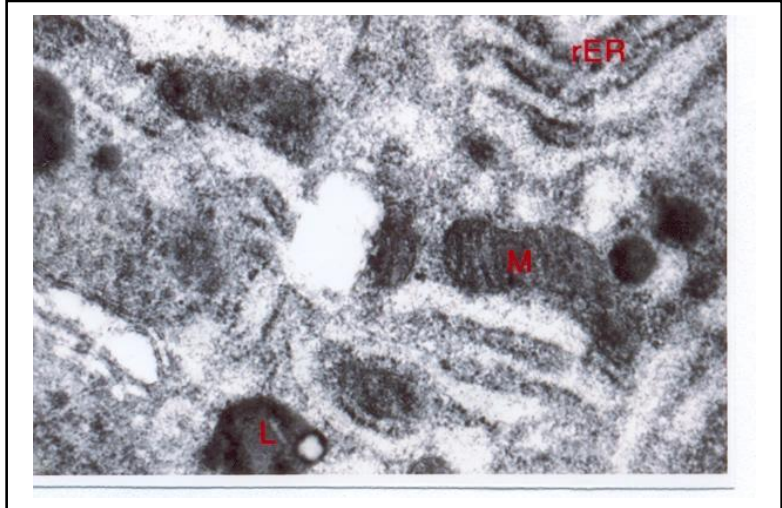

Fig. (10): An electron micrograph of a part of follicular cell in therapeutic dose treated group. Showing inclusion lysosomes (L), distended mitochondria with glycogen with loss of its pattern \& marked dilated rER.

( X 20000)

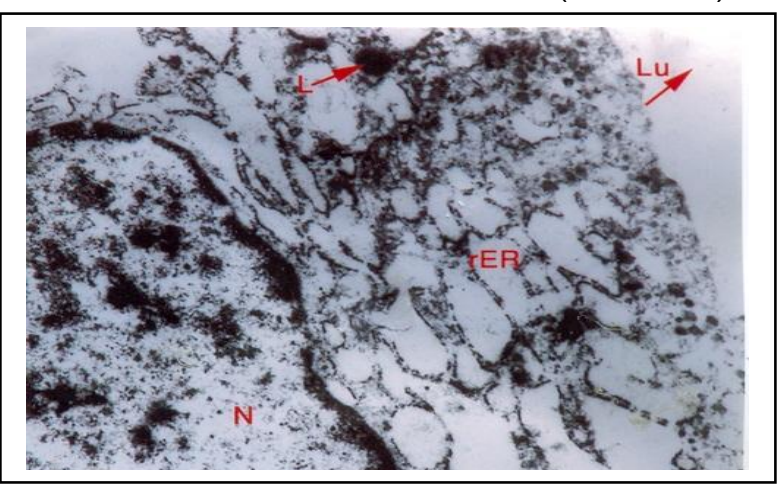

Fig. (12): Electron micrograph of follicular thyroid cell in toxic dose treated group showing distended irregular $\mathrm{rER}$ and secretory granules $\uparrow \uparrow \uparrow$ near the lumen (Lu). Notice: Lysosomal inclusion bodies (L).

( X 8000)

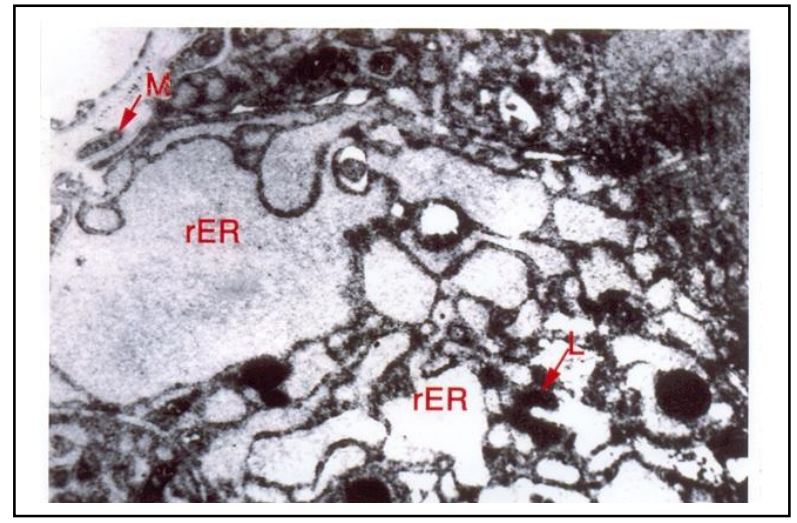

Fig. (14): Electron micrograph of thyroid follicular in toxic dose treated group showing marked dilated irregular distended rER, many deformed secondary deformed lysosomes (L) and elongated mitochondria (M). (X 20000) 


\section{Ola A. El Sayed et al}

\section{Discussion}

Amiodaron was used in the management of cardiac dysarrnhythmias. Accumulation of amiodarone in the thyroid gland might result in gland dysfunction, either hypothyroidism or thyrotoxicosis (Smeck et al., 1987).

It was found in both therapeutic and toxic doses treated groups that there were very highly significant decrease in body weight. These results were in agreement with (Bartelena et al., 2001) who stated that chronic exposure to amiodarone therapy had been observed to cause reduction of body weight as a sign of thyrotoxicosis. These results explained that reduction in body weight was due to elevated (T3 and T4) hormones.

As regards the biochemical results emerged from the present study, there were a very highly significant increase in the levels of T3 and T4 and a very highly significant decrease in TSH. These results were in accordance with (Balzano et al., 1987) who stated that amiodarone induced thyrotoxicosis (AIT) was diagnosed by increased serum free (T4) and decreased serum TSH concentration.

The characteristic features of amiodarone induced thyrotoxicosis was associated with preferential secretion of $\mathrm{T} 4$. It was suggested by high $\mathrm{T} 4 / \mathrm{T} 3$ ratio. (Briancon, 1990).

These results were in contrary with Burger, et al., (1976) who demonstrated the effects of amiodarone on the peripheral metabolism of thyroid hormones to result in low T3 syndrome in patients treated chronically with the drug.

Diagnosis of amiodarone induce thyrotoxicosis revealed increased serum free T4, decreased or suppressed serum TSH and decreased serum total and free T3 concentration. Serum thyroglobulin was often increased in AIT, but this might not represent a good marker of thyroid destruction in goiterous patients. (Martino et al., 1987 \& Anu Bhalla, 2007).

There were a very highly significant increase in the level of IL6 in both treated groups This result was in agreement with (Brtalenal et al., 1994) who stated that thyrotoxicosis related to amiodarone therapy exhibited destructive thyroditis when was associated with very high serum IL6 levels, glucocorticoid administration was the treatment of choice.

As regards levels of P53 protein concentration, it showed a very highly significant increase in both treated groups and this was in agreement with (Holt et al., 1983) who stated thatP53 elevated in cases of amiodarone induced thyrotoxicosis which induced apoptosis in thyroid gland. Hormonal bioassay in the present investigation revealed an unbalanced serum thyroid hormones which seemed to be a reflection of the histological changes of the thyroid gland upon amiodarone exposure (Capen, 1994).

As regards amiodarone concentration in tissues, it showed significant increase in plasma, fat, liver, lung, thyroid gland and heart in therapeutic dose treated group and a highly significant increase in toxic dose treated group. Fat, liver, and lung were the tissues with the greatest amiodarone concentration at the end of the experiment while the least concentration present in the other organs including thyroid, heart and plasma. This was explained by (Chiovate et al., 1994) who explained the cytotoxic effect of amiodarone on thyroid cells which was mainly due to toxic action of its metabolite (Desethlamiodarone) which even more cytotoxic for thyroid cells than amiodarone and its intrathyroidal concentration was higher than that of the parentral drug.

The distribution of antiarrhythmic drug amiodarone and its principle lipophilic metabolite was determined in postmortem tissues. It was found that its concentration was highest in liver, lung, adipose tissue and pancrease, , followed by kidney, heart (left ventricle) and thyroid gland. It is the lowest in antimorttem plasma. (Brien et al., 1987 and Martino et al., 2001).

Concerning the histopathlogical examination it also afforded evidence of the development of thyrotoxicosis which was marked in therapeutic dose treated group and became severe in toxic dose treated group. 
Light microscopic examination of group II, thyroid tissue revealed loss of normal architecture, irregular shape and size of acini with microcystic follicular changes and peripheral scalloping with scanty amount of colloid. Signs of cellular degeneration as scanty cytoplasm and vesicular nuclei were detected.

Light microscopic examination of group III, thyroid tissue revealed marked epithelial hyperplasia of the thyroid follicles with atypical nuclear features. Thyroid acini became lined with stratified columnar cells. Thyroid tissue showed follicular damage with haemrrhage. Interstitial tissue showed fibrosis with inflammatory cell infiltration, and areas of haemorrhage and necrosis. These findings are in agreement with (Smeck et al., 1987 and Alcan et al., 1990) who described the pathological effects of amiodarone associated with thyrotoxicosis. Thyroid gland showed damage, degenerative and destructive follicular lesions with diffuse fibrous tissue lymphocytic infiltration.

There was also loss of follicular epithelial cells with macrophages in the colloid and fibroblast creating fibrous tissue. (Gough and Gough, 2002).

As regard electron microscopic changes of thyroid follicular cells, it showed marked effect in therapeutic dose treated group while it became more marked and severe in toxic dose treated group. It showed dilated rouph endoplasmic reticulum, many large inclusion lysosomes and dilated cisternae of Golgi bodies. The nucleus showed irregular dispersed chromatin \& irregular nuclei. Mitochondria appeared to be distended with glycogen with loss of its pattern. There were secretory vesicles and granules near the lumen. These results were in agreement with (Cappielo et al., 1995 and Pitsiavas 1997) who described the electron microscopic changes due to toxic effect of aminodarone on thyroid gland. Multilamellar lysosomal inclusions, intramitochondrial glycogen-inclusions-both ultrastructural findings indicated thyroid cell damage and a microscopic morphological pattern of thyroid cell hyperfunction.

\section{Conclusion And Recommendation}

In conclusion, amiodarone use decreases body weight, increases thyroid hormones, IL6, and P53 with cumulative tissue residue tendency. Also it caused histopathological findings in the form of light microscopic and ultrastructural changes. So we recommended for the patients receiving amiodarone therapy to be carefully evaluated before and during treatment. Thyroid gland examination and thyroid ultrasound on initial evaluation should be done. Baseline serum TSH, total and free $\mathrm{T} 4$, total and free $\mathrm{T} 3$ concentrations are recommended, so that changes in thyroid function can be monitored.

\section{References}

1. Alan P, Farwell Su San $\mathbf{L}$ and Lewis $\mathbf{E}$ (1990): Thyroidectomy for amiodarone induced thyrotoxicosis JAMA, 16: 263. 11.

2. Altman G A (1991): Practical statistics for Medical Research, Ist, ed., Chapman and Hall, London. Pp. 156.

3. Anu Bhalla D (2007): Toxic nodular goiter \& hyperthyroiditis by amiodarone: Medicine, 30,: 50 - 52

4. Balzano S, Sau F, Bartalena $L$ and Martino E (1987): Diagnosis of amiodarone-iodine-induced thyrotoxicosis (AIT). J Endocrinol. Invest., 10: 589 - 591)

5. Bannes M, Dublin A, Ficher J, Levison D and Millis R (1993): Detection of P53 protein mammary carcinoma. Hmo Pathol., 24: 469 - 476.

6. Bdrtalena L, Brogioni $S$ and Martinoe (1994): Interleukin-6: a marker of thyroid destructive processes J-clin- EndocrinolMetab., 79 (5): 1424 - 7.

7. Bartalena L, Bogazzi $\mathbf{F}$ and Breaverman G (2001): Effects of amiodarone administration during pregnancy as neonatal thyroid function and subsequent neurdeveloment. J. endocrinol, Invest 24:275- 283.

8. Briancon C, Halpern S, Telenczak $\mathbf{P} \&$ Fragu $P$ (1990): Changes in ${ }^{127}$ I mice thyroid follicle studied by analytical ion microscopy: a key for the comprehensionion of amiodarone-induced thyroid disease. Endocrinology, 127: 1502 - 9.

9. Brien J F, Brennan $\mathbf{F} \mathbf{J}$ and Armstrong $\mathbf{P}$ W (1987): Distribution of amiodarone and its metabolite in human tissues. Can-Jphysiol-pharmacol., 65(3): $360-4$. 


\section{Ola A. El Sayed et al}

10. Burger A, Dinichert D, Nicod P, Jenny M, Lemaachand-Beraud $T$ \& Valloton $M$ (1976): Effect of amiodarone on serum T3, T4 and TSH. A drug influencing peripherals metabolism of thyroid hormones J. Clin invest., 58:255 - 9.

11. Capen C (1994): Mechanisms of chemical injury of thyroid gland. Prog.Clin.Biol. res: 387: 173 - 91 .

12. Cappiello E, Boldorini R, Tosoni A and Piraneo-S (1995): ultrastructural evidence of thyroid damage in amiodarone induced thyrotoxicosis. J. Endocrinol-Invest., 18 (11): $862-8$.

13. Chiovato L, Martino $\mathbf{E}$ and Tonacchera M (1994): Studies on the in vitro cytotoxic effect of amiodarone. Endocrinology, 134: $2277-2282$.

14. Drury $R$ A and Wallington E A (1980): "Carlton's Histological techniques" $7^{\text {th }}$ Ed. Oxford University Press, New York, Toronto; P. 137 - 145.

15. Gough $\mathbf{R}$ and Gough J (2002): Surgical management of amiodarone associated thyrotoxicosis. MJA, 176: 128 - 129.

16. Hardman J G, Limbird L L, Molinoff $P$ $B$ and Ruddon $R$ W (1996): Antiarrhythmic drugs, in "Good man and Gilman's" "The pharmacological basis of therapeutics". $9^{\text {th }}$ Ed. Mc Grow Hill press, New York, St. Vovis. P. 858 - 860.

17. Hayat M A (1989): Principals and techniques of electron microscopy \& biological applications. $3^{\text {rd }}$ ed., McMillan Press. London.

18. Holt DW, Tucker GT And Jackson PR (1983): Amiodarone pharmaco kinetics. Am. Heart J. 106: 843 - 47.

19. Kaplan M M (1985) Clinical and laboratory assessment of thyroid abnormalitied. Medical clinics of North America, 96: 112-120.

20. Knnon R, Sarma JS, Guha M \& Venkataraman K (1991): Amiodarone toxicity in rats; Fundam. Appl. Toxicol., 16 (1): $103-9$.

21. Martino E, Aghini Lombardi F and Mariottis B (1987): Amiodarone : a common source of Iodine induced thyrotoxicosis. Horm. Res., 26: $158-171$.

22. Mulligan D C, Mchenry C $\mathbf{R}$ and Esselstyn C B (1993): Amiodaroneinduced thyrotoxicosis: clinical presentation and expanded indications for thyrodectomy. 114(6): $1114-9$.

23. Najjar TA (2001): Disposition of amiodarone in rats after single and multiple doses. Eur. J. Drug Metab pharmacoknit. 26(1): $65-9$.

24. Neill $H$ and Stacey $M$ (1993): Occupational toxicology, London, Taylon and Francis Ltd., pp. 416 - 419.

25. Paget G E and Barnes J M (1964): "Evaluation of drug activities and pharmaceutics" $1^{\text {st }}$ Ed. Academic press. London., 135 - 155.

26. Pitsiavas V, Smerdely $P$ LiM And Boyagess SC (1997): Amiodarone induces a different patten of ultrastructural change in the thyroid to iodine excess along in the wistern rat. Eur, J. Endocrinol., 137: 89 98.

27. Reader E A, Podrid PJ and Lown B (1985): Side effects and complications of amiodarone therapy. Heart. J,. 109: 975 983.

28. Smek T C, Goelner J R, Branan M D and Curyney J A (1987): Pathology of the thyroid in amiodarone induced thyrotoxicosis. Am. J. surg. Pathol., 11: 197 - 204. 
دراسة التأثير السمى لعقار الأميودارون على الغدة الدرقية من الناحية الهستولوجية والكيميائية فى الفئران البيضاء الغئراء

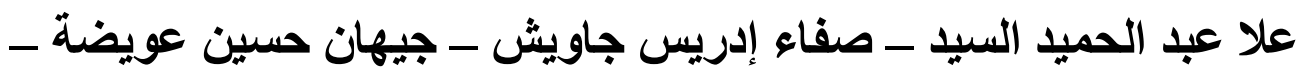

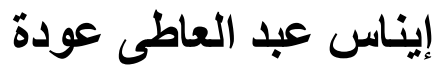

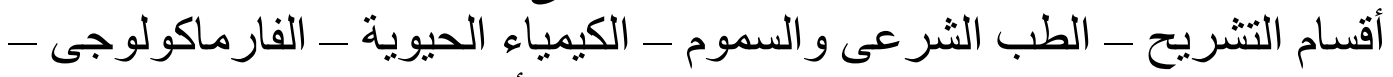

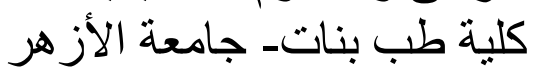

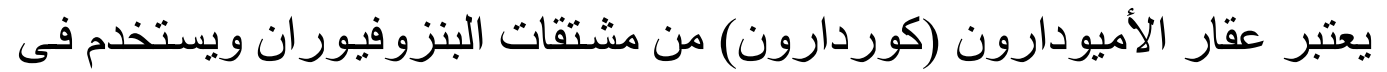

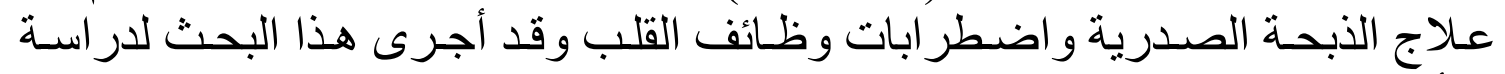

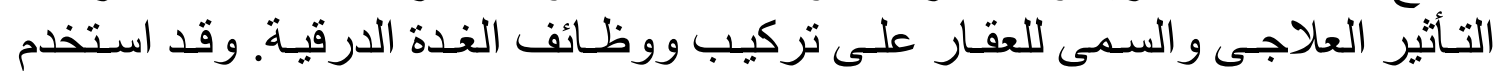

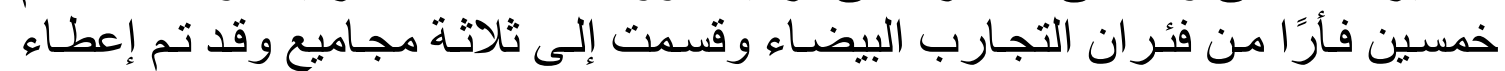

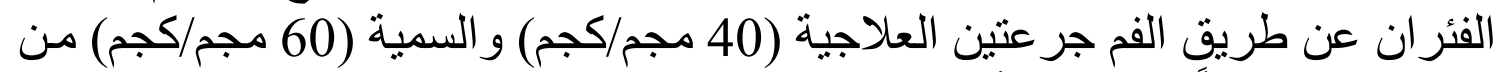

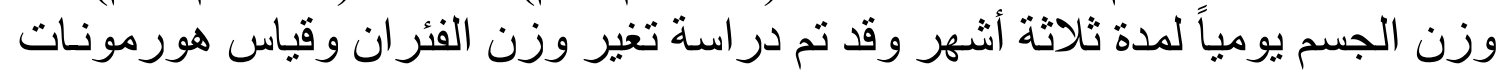

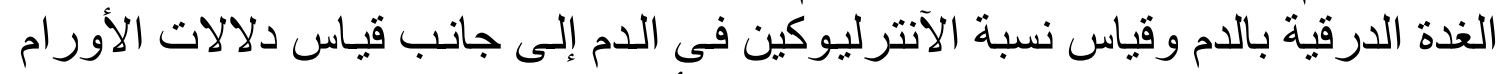

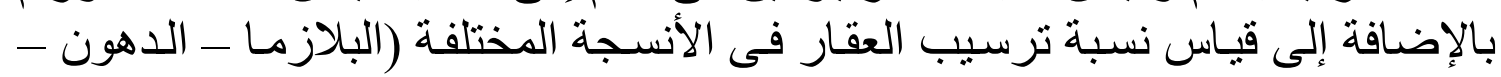

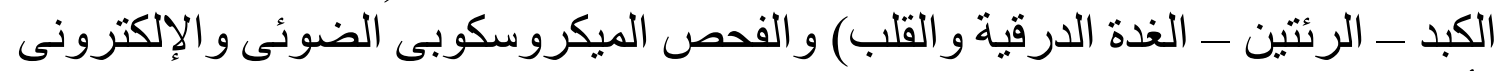

وقد أوضحت النتائج النقص الملحوظ و الثديد فى الوزن فى الجر عتين العلاجية

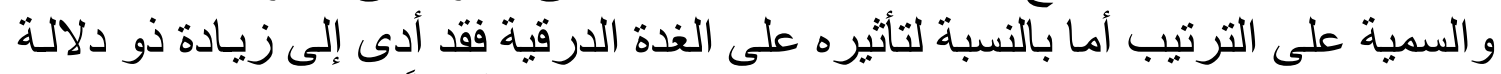

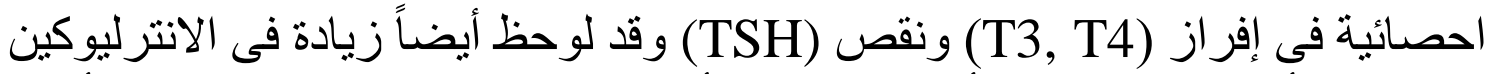
ودلالات الأورام (P53) وقد أظهرت النتائج أن ترسيب العقار فى الكبد و الدهون أعلى لألى

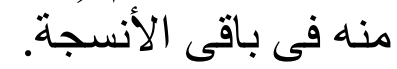

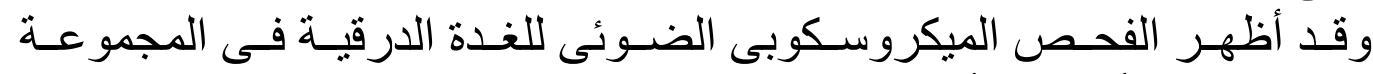

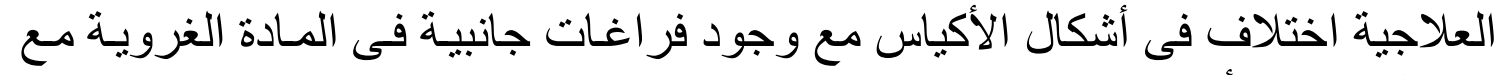

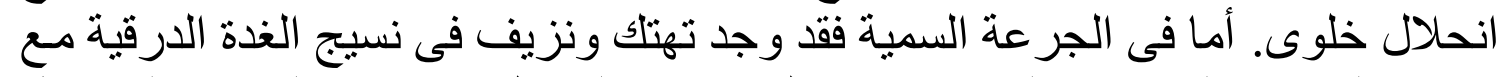

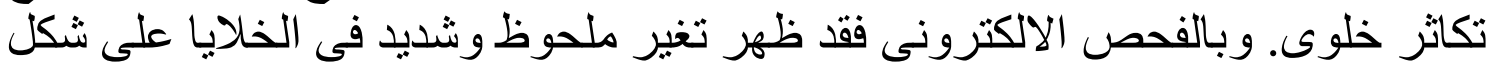

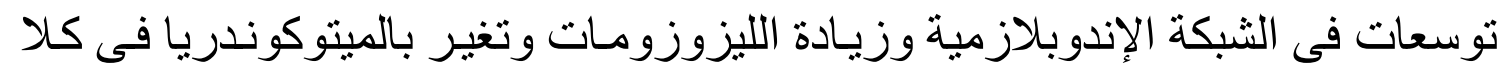
المجمو عتين العلاجية و السمية على الترتيب. 